\title{
SKRINING BAKTERI SELULOLITIK ASAL SALURAN PENCERNAAN RAYAP UNTUK MENDEKOMPOSISI TUNGGUL KARET
}

\author{
(Screening of cellulolytic bacteria origined from termite gut for decomposing \\ rubber tree stump)
}

\author{
Silviana Arsyad $^{1 *}$, Suryo Wiyono ${ }^{2}$, Elis Nina Herliyana ${ }^{3}$
}

(Diterima Agustus 2017/Disetujui Oktober 2017)

\begin{abstract}
The rubber tree stump is a source of white root fungus inoculums and as a source of infection that causes the death of rubber plant. The emergence of this disease is closely related to the cleanliness of the land such as leftover trees or stumps, shrubs and bushes which stacked or still in the ground. One of the symbionts organisms found in gut of termite and play a role in the decomposition of cellulose, are bacteria. Termite are social insects that are efficiently decompose lignocelluloses with the aid of their associated microbial symbionts located in termite gut. The purpose of this study was to obtain cellulolytic bacterial isolates are derived from gut of termite and getting an cellulolytic which showed the best ability in decomposing rubber tree stumps. The result termite samples from oil palm, rubber, and dry wood contain cellulolytic bacteria characterized by clear zones around bacterial colonies. Bacterial isolates showing the ability to degrade cellulose are 31 isolates and five isolates are safe for plants, animals, or mammals. The three bacterial isolates (NK 4, NS 4, and NS 5) used in the test on rubber tree stumps able to decompose rubber tree stump. Bacterial isolates were each obtained NK 4 13.52\%, NS $418.40 \%$ and NS $517.88 \%$.
\end{abstract}

Keywords: bacteria cellulolytic, rubber tree stumps, termite

\section{PENDAHULUAN}

Tunggul karet merupakan sumber inokulum jamur akar putih dan sebagai sumber infeksi yang menyebabkan tanaman karet mengalami kematian. Nugroho (2012) dan Manurung et al. (2015) melaporkan bahwa di lahan tanaman karet sering terjadi serangan jamur Rigidoporus microporus (=R. lignosus) penyebab penyakit akar putih yang hidup dari sisa-sisa bagian tunggul karet. Timbulnya penyakit ini erat hubungannya dengan kebersihan lahan seperti sisa tebangan pohon atau tunggul, perdu, dan semak yang ditumpuk atau yang masih berada dalam tanah. Hal ini merupakan sumber penularan jamur akar putih yang sangat efektif serta mudah menyebar ke tunggul lainnya. Nugroho dan Iswanto (2009) menyebutkan bahwa ketersediaan alat pencacah di Indonesia masih sangat terbatas dan relatif mahal. Sehingga dalam memusnahkan tunggul karet atau sisa hasil tebangan kayu karet diperlukan bioteknologi.

\footnotetext{
1 Mahasiswa Pascasarjana Bioteknologi Tanah dan

Lingkungan, Sekolah Pascasarjana, IPB

* Penulis korespondensi:

e-mail: silvianaarsyad@gmail.com

2 Staff Pengajar Dept. Proteksi Tanaman, Fakultas

Pertanian, IPB

3 Staff Pengajar Dept. Silvikultur, Fakultas Kehutanan, IPB
}

Alternatif yang dapat ditempuh dengan bioteknologi pelapukan tunggul karet yaitu menggunakan mikrob pelapuk kayu dari kelompok bakteri selulolitik. Kayu tersusun atas lignin, selulosa, dan hemiselulosa. Bakteri selulolitik dipilih sebagai salah satu mikrob pendegradasi selulosa. Bakteri memiliki tingkat pertumbuhan yang lebih cepat dan mudah dikontrol dibandingkan dengan kelompok mikrob lainnya (Baharuddin et al. 2010). Bakteri selulolitik yang digunakan dapat berasal dari saluran pencernaan rayap. Pada umumnya rayap merupakan serangga sosial yang efisien dalam mendekomposisi lignoselulosa dengan bantuan mikrob simbionnya, yang berada dalam saluran pencernaan (Chew 2012; Upadhyaya et al. 2012). Rayap umumnya ditemukan pada kayu mati atau pohon hidup, di hutan, dan juga pada kayu kontruksi rumah. Disatu sisi, keberadaan rayap sering kali menjadi serangga perusak kayu bagi tanaman perkebunan dan kontruksi bangunan. Disisi lain, rayap memiliki peran sangat penting dalam ekosistem tanah yaitu dalam proses daur ulang biomasa lignoselulosa kayu. Rayap yang berasal dari kelapa sawit, kayu karet dan kayu kontruksi berpotensi sebagai sumber bahan selulolitik. Semua bahan yang mengandung selulosa seperti kayu merupakan sumber makanan utama rayap. Tujuan penelitian ini ialah 1) mendapatkan bakteri selulolitik yang berasal dari saluran pencernaan rayap dan 2) memperoleh bakteri selulolitik potensial dalam mendekomposisi tunggul karet. 


\section{METODE PENELITIAN}

\section{Waktu dan Tempat Penelitian}

Penelitian ini dilaksanakan pada Januari 2016 sampai Februari 2017. Penelitian ini dilaksanakan di Laboratorium Bioteknologi Tanah, Departemen Ilmu Tanah Sumberdaya Lahan, Fakultas Pertanian dan Laboratorium Penyakit Hutan, Departemen Silvikultur, Fakultas Kehutanan, Institut Pertanian Bogor.

\section{Alat dan Bahan Penelitian}

Alat-alat yang digunakan dalam penelitian ini antara lain cawan Petri, tabung reaksi, shaker, autoclave, timbangan analitik, mikroskop cahaya, mikroskop stereo, inkubator dan Laminar air Flow (LAF). Bahan yang digunakan dalam penelitian ini terdiri atas rayap tanaman kelapa sawit, kayu karet, dan kayu kontruksi, alkohol 70\%, aquades steril, media NA (Nutrient Agar), media TSB (Trypticase Soy Broth), media CMC (Carboxymethyl Cellulose), pasir kuarsa, dan tunggul karet.

\section{Pengambilan Contoh Rayap}

Pengambilan contoh rayap berasal dari rayap kelapa sawit, rayap karet dan rayap kayu kering kontruksi di dalam kampus IPB. Contoh rayap yang diperoleh disimpan dalam wadah plastik dan diberi label untuk masing-masingnya.

\section{Isolasi Bakteri Selulolitik Asal Saluran Pencernaan Rayap}

Isolasi bakteri pada saluran pencernaan rayap dengan mengambil sebanyak 10 ekor untuk setiap perlakuannya. Selanjutnya dilakukan sterilisasi permukaan rayap menggunakan alkohol $70 \%$ selama 30 detik dengan cara dicelupkan. Sterilisasi permukaan rayap dilakukan untuk mematikan atau meminimalkan mikrob kontaminan. Setelah sterilisasi rayap dibilas dengan aquades steril dan dikering udara selama 1 menit. Perut rayap di bedah dalam keadaan steril. Saluran pencernaan rayap yang diperoleh kemudian digerus hingga menjadi suspensi.

Suspensi saluran pencernaan rayap di masukkan pada tabung eppendorf dengan menambahkan aquades steril $1 \mathrm{ml}$. Sebanyak $1 \mathrm{~mL}$ diambil dan di tambahkan ke dalam tabung reaksi yang berisi aquades steril sebanyak $9 \mathrm{ml}$ pada pengenceran berseri yaitu $10^{1}$ sampai $10^{5}$. Kemudian mengambil sebanyak $0.1 \mathrm{~mL}$ dan disebar pada media NA dan TSA. Inkubasi pada suhu $37^{\circ} \mathrm{C}$ selama tiga hari.

\section{Skrining Isolat Bakteri Selulolitik}

Isolasi bakteri selulolitik asal saluran pencernaan rayap menggunakan media selektif carboxymethyl cellulose sebagai sumber karbon tunggal dan untuk melihat aktivitas selulosanya. Isolat bakteri pada media agar NA dan TSA yang tumbuh diambil menggunakan jarum ose dalam keadaan aseptis dan di goreskan pada media CMC agar. Media tersebut diinkubasi pada suhu $30^{\circ} \mathrm{C}$ selama seminggu.

\section{Karakterisasi Bakteri Selulolitik Asal Saluran Pencernaan Rayap}

Karakterisasi bakteri dilakukan untuk mengetahui jenis bakteri selulolitik. Isolat bakteri yang telah diisolasi diamati secara morfologi yaitu dilihat dari segi bentuk, warna, margin, elevasi, permukaan dan ukuran koloni. Isolat bakteri yang telah diisolasi diamati secara biokimia yaitu dilihat menggunakan uji Gram, uji motilitas, uji katalase, uji oksidase, uji oksidatif fermentatif, uji hidrolisis pati, uji hipersensitif, uji agar darah, dan uji kemampuan selulosa.

\section{Uji Keefektifan Bakteri Selulolitik Terpilih dalam Dekomposisi Tunggul Karet}

Pengujian keefektifan bakteri selulolitik pada tunggul karet menggunakan Rancangan Acak Lengkap dengan satu faktor yaitu jenis bakteri yang terdiri dari empat perlakuan dan empat ulangan. Metode yang digunakan adalah metode modifikasi JIS K 1571 (JIS 2004). Pengujian bakteri selulolitik pada tunggul karet dilakukan dengan beberapa tahapan yakni pengambilan tunggul karet uji. Tunggul karet di potong dengan ukuran $2 \mathrm{~cm} \times 2 \mathrm{~cm} \times 1 \mathrm{~cm}$ dengan arah pemotongan serat cross, mengikuti metode standar yang sesuai dengan JIS K 1571.

Penyiapan biakan bakteri selulolitik. Media biakan bakteri yang digunakan adalah media TSB (Trypticase Soy Broth). Media biakan bakteri ini menggunakan pasir kuarsa steril yang telah dicampurkan dengan media TSB cair. Sebanyak $40 \mathrm{ml}$ media tersebut dimasukkan ke dalam botol uji dan ditutup. Botol uji yang telah berisi media biakan TSB disterilkan ke dalam autoklaf selama 30 menit pada tekanan 15 psi. Bakteri selulolitik diinokulasi sehari kemudian. Tahapan terakhir pengujian keefektifan penguraian bakteri selulolitik pada tunggul karet. Memasukkan tunggul karet uji yang telah steril dan ditimbang bobotnya ke dalam botol uji. Pengujian keefektifan penguraian tunggul karet uji dilakukan selama 12 minggu. Tunggul karet uji dipanen dan di masukkan ke dalam oven selama 24 jam pada suhu $60^{\circ} \mathrm{C}$ dan ditimbang. Presentase penurunan bobot dihitung atas dasar selisih bobot tunggul karet sebelum dan sesudah diaplikasikan dengan bakteri selulolitik.

Perhitungan presentasi penurunan bobot tunggul karet dengan menggunakan rumus sebagai berikut:

Dimana,

$$
P=\frac{W 1-W 2}{W 1} \times 100 \%
$$

$\mathrm{P}$ : Persentase penurunan bobot $(\%)$

$\mathrm{W}_{1}$ : Bobot kering tanur contoh uji sebelum diumpankan $(\mathrm{g})$

$\mathrm{W}_{2}$ : Bobot kering tanur contoh uji setelah diumpankan (g)

\section{Analisis Data}

Hasil penelitian dianalisis menggunakan Analisis of Variance (Anova) dengan Software SAS (Statistical analysis system) dan data kualitatif disajikan dalam bentuk tabel dan gambar. Jika terdapat pengaruh signifikan maka dilakukan uji lanjut Duncan Multiple Range Test (DMRT) 5\%. 


\section{HASIL DAN PEMBAHASAN}

\section{Pengambilan Contoh Rayap di Lapangan}

Contoh rayap berasal dari tanaman kelapa sawit, karet dan kayu kering kontruksi di ambil dari daerah Cikabayan Kampus IPB Dramaga (Gambar 1). Hasil penelitian ini menunjukkan bahwa rayap kelapa sawit termasuk spesies Odontotermes sp. terlihat dari bentuk kepala kasta prajurit berwarna coklat tua atau coklat kemerahan dan ciri tubuh berwarna kuning. Rayap ini banyak ditemukan di perkebunan sawit (Gambar 1a). Rayap karet termasuk spesies Microtermes sp. terlihat dengan bentuk kepala kasta prajurit berwarna coklat tua atau kemerahan dan memiliki ciri tubuh berwarna kuning terang (Gambar 1b). Rayap ini banyak ditemukan di kayu-kayu yang sudah lapuk dan biasanya mengeluarkan bau yang khas. Nandika et al. (2015) melaporkan kelimpahan spesies rayap Microtermes insperatus Kemmer di kampus IPB Dramaga paling banyak dibandingkan spesies yang lain dan mempunyai kelimpahan yang tinggi di perkebunan karet dan kelapa sawit. Rayap kayu kering kontruksi termasuk spesies Cryptotermes sp. terlihat dari bentuk kepala berwarna coklat gelap kemerahan (Gambar 1c). Spesies ini banyak ditemukan menyerang di permukiman sehingga menyebabkan kerusakan dalam kayu.

\section{Isolasi, Skrining Bakteri Asal Saluran Pencernaan Rayap yang Bersifat Selulolitik}

Isolat bakteri asal rayap kelapa sawit, karet dan kayu kering kontruksi diperoleh 111 isolat bakteri. Pada skrining awal sebanyak 31 isolat bakteri yang menunjukkan zona bening pada media agar CMC. Hal ini karena bakteri selulolitik mampu tumbuh yang ditandai dengan zona bening di sekitar koloni. Terbentuknya zona bening menjadi indikasi bahwa isolat bakteri tergolong bakteri selulolitik. Igwo et al. (2013) dan Ngangi et al. (2013) melaporkan bahwa zona bening di sekitar koloni menunjukkan pemanfaatan selulosa sebagai satu-satunya sumber karbon, energi dan substrat dari CMC dihidrolisis oleh enzim selulase. Selanjutnya isolat bakteri yang terbentuk zona bening dipilih untuk pengujian patogenisitas. Hal ini dilakukan untuk meminimalkan isolat dalam pengujian ke tahap berikutnya serta mendapatkan isolat bakteri yang aman bagi tanaman, mamalia ataupun hewan (Gambar 2).

Hasil uji hipersensitif pada daun tembakau hanya isolat TS 18 yang menunjukkan reaksi hipersensitif positif. Hal ini karena daun tembakau menunjukkan gejala nekrosis pada bagian daun yang disuntikan suspensi bakteri uji. Pradana (2016) melaporkan bahwa membran seluler pada daun tembakau yang mengalami kontak dengan bakteri akan hancur dan mengalami pengeringan atau gejala nekrosis diindikasi sebagai patogen tanaman. Tanaman tembakau memiliki sensitivitas yang cukup tinggi dan morfologi daun yang cukup tebal sehingga tidak menimbulkan rusaknya fisik daun (Rupaedah 2014). Bakteri yang tidak menunjukkan gejala nekrosis pada uji hipersensitif dilakukan uji hemolitik yang aman bagi hewan atau mamalia. Hasil uji hemolitik diketahui lima isolat bakteri yang aman bagi mamalia. Hal ini diduga karena bakteri tersebut tidak mampu dalam melisis media agar darah. Sebanyak 25 isolat bakteri yang memperlihatkan zona bening di sekitar koloni. Hal ini dapat menimbulkan patogen bagi hewan atau mamalia.

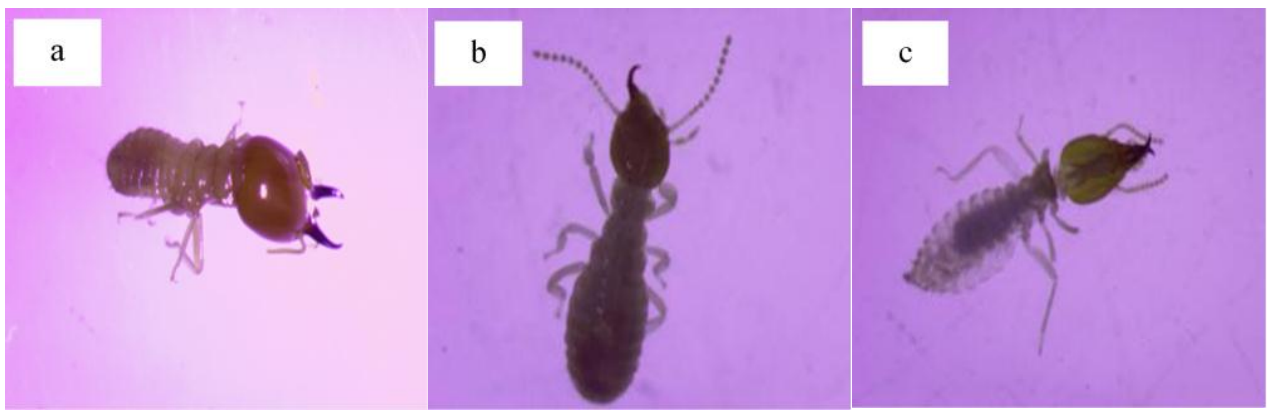

Gambar 1 (a) Rayap Kelapa Sawit termasuk spesies Odontotermes sp., (b) Rayap Karet termasuk spesies Microtermes sp., dan (c) Rayap Kayu Kering Kontruksi termasuk spesies Cryptotermes sp.

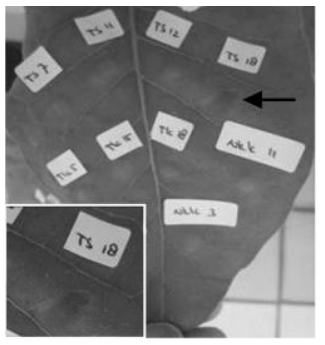

a

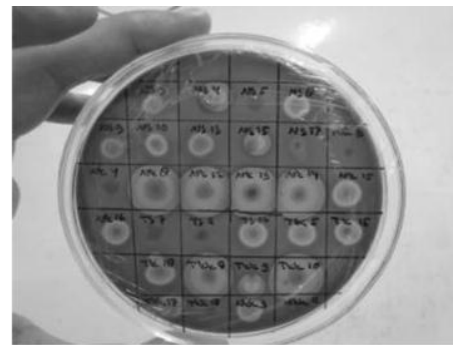

b

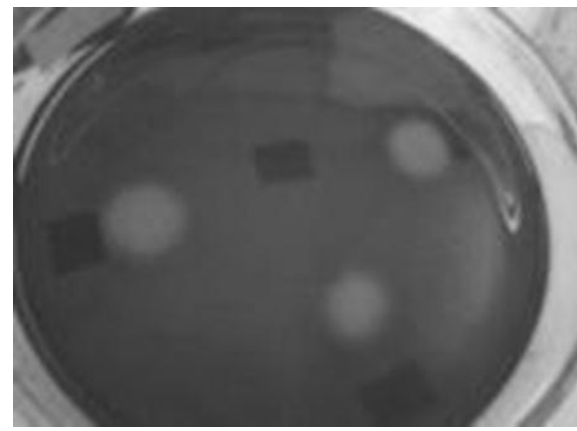

Gambar 2 Hasil uji isolat bakteri (a) Uji Hipersensitif pada daun tembakau, dan (b) Uji hemolitik pada media agar darah

Gambar 3 Uji kemampuan bakteri selulolitik dengan media CMC agar 
Suryanto et al. (2007) melaporkan bahwa isolat yang mampu melisiskan darah pada media agar darah ditandai dengan adanya zona bening.

Hasil uji kemampuan bakteri selulolitik menunjukkan bahwa tiga isolat bakteri yang membentuk zona bening (Gambar 3). Isolat NK 4 memiliki indeks selulolitik terbesar dengan nilai 9 dan isolat NK 3 dan TKK 18 memiliki indeks selulolitik terkecil terlihat pada Tabel 1. Bajya et al. (2015) menandakan aktivitas selulolitik tertinggi dan terendah dilihat dari diameter zona bening yang memiliki kemampuan dalam mendegradasi selulosa pada media CMC agar. Kakkar et al. (2015) melaporkan bakteri selulolitik yang berasal dari saluran pencernaan rayap Odontotermes parvidens memiliki indeks selulolitik 3.0. Dengan demikian, kemampuan bakteri dalam menghasilkan selulase tertinggi mengindikasikan bahwa isolat bakteri memiliki kemampuan aktivitas selulolitik. Upadhyaya et al. (2012) juga melaporkan bahwa untuk setiap koloni memiliki produksi diameter zona bening yang berbedabeda dan sebagai dasar perbandingan strain yang digunakan. Selanjutnya, ketiga isolat bakteri ini dipilih untuk pengujian keefektifan bakteri selulolitik dalam mendekomposisi tunggul karet.

\section{Karakterisasi Bakteri Selulolitik Asal Saluran Pencernaan Rayap}

Sebanyak tiga isolat bakteri menunjukkan karakterisasi morfologi koloni asal rayap sebagian besar berbentuk bulat dengan permukaan halus mengkilap,

Tabel 1 Kemampuan selulolitik bakteri terpilih

\begin{tabular}{cc}
\hline Kode isolat & Indeks Selulolitik (IS) \\
\hline NK 3 & Tu \\
NK 4 & 9 \\
NS 4 & 1.2 \\
NS 5 & 4.2 \\
TKK 18 & Tu \\
\hline
\end{tabular}

Ket : NK = rayap karet $; \mathrm{NS}=$ rayap sawit $; \mathrm{TKK}=$ rayap kayu kering ; Tu $=$ tidak terukur margin entire, serta elavasi cembung dengan warna koloni berwarna putih, krem dan bening. Pada umumnya semua spesies rayap memiliki elevasi cembung (Mubin 2013) (Tabel 2).

Uji biokimia untuk isolat bakteri NK 4 dan NS 4 memiliki hasil yang positif pada motilitas, katalase, dan hidrolisis pati sedangkan hasil negatif pada oksidase dan fermentasi oksidatif. Hal ini sesuai dengan Pourramezan et al. (2012) yang menghasilkan katalase dan oksidase yang bersifat positif dan negatif. Isolat bakteri NS 5 memiliki hasil yang positif pada motilitas dan hidrolisis pati. Katalase, oksidase, dan fermentasi oksidatif memiliki hasil yang negatif, hal ini diduga karena bakteri tersebut tidak dapat mengdegradasi hidrogen peroksida menjadi oksigen bebas dan tidak menghasilkan $\mathrm{H}_{2} \mathrm{O}_{2}$ atau $\mathrm{H}_{2} \mathrm{O}$. Sunatmo (2009) melaporkan bahwa akumulasi senyawa dapat menyebabkan kematian bila tidak segera didegradasi. Selain itu, ketidakmampuan mikrob anaerob mutlak untuk mensintesis katalase, peroksidase atau superoksida dismute yang menyebutkan bahwa oksigen bersifat toksis bagi mikrob tersebut.

\section{Uji Keefektifan Bakteri Selulolitik Terpilih dalam Dekomposisi Tunggul Karet}

Pengamatan visual kayu dilakukan untuk melihat pengujian dekomposisi tunggul karet ke dalam biakan bakteri selama tiga bulan. Dari hasil pengamatan terlihat jelas dengan adanya perubahan warna pada kayu akibat biakan bakteri. Contoh uji tunggul kayu yang telah diserang bakteri mengalami perubahan warna menjadi coklat tua. Perubahan warna pada contoh uji tunggul karet memperlihatkan warna kayu dari warna coklat muda menjadi berwarna coklat tua. Perubahan warna kayu ditandai dengan permulaan pembusukan, jarang nampak karena diakibatkan warna dari kayu itu sendiri. Hasil pengujian contoh uji kayu menggunakan metode JSI K 1571 memperlihatkan tampilan warna kayu berwarna coklat dan sebagian besar isolat bakteri menyelimuti contoh uji kayu pada media pasir kuarsa.

Tabel 2 Karakterisiasi morfologi dan biokimia bakteri selulolitik asal saluran pencernaan rayap

\begin{tabular}{|c|c|c|c|}
\hline \multirow{2}{*}{ Karakterisasi } & \multicolumn{3}{|c|}{ Kode isolat } \\
\hline & $\mathrm{NK} 4$ & NS 4 & NS 5 \\
\hline Asal isolat & Rayap Karet & Rayap Sawit & Rayap Sawit \\
\hline \multicolumn{4}{|l|}{ Morfologi koloni : } \\
\hline Warna & Krem & Putih & Bening \\
\hline Bentuk & Bulat & Tak beraturan & Bulat \\
\hline Elavasi & Cembung & Cembung & Rata \\
\hline Margin & Rata & Rata & Rata \\
\hline Permukaan & Halus mengkilap & Halus mengkilap & Halus mengkilap \\
\hline Bentuk sel & Streptokokus & Kokus & Basil \\
\hline Uji Gram & + & + & + \\
\hline \multicolumn{4}{|l|}{ Biokimia : } \\
\hline Motilitas & + & + & + \\
\hline Katalase & + & + & - \\
\hline Oksidase & - & - & - \\
\hline Hidrolisis pati & + & + & + \\
\hline Fermentasi Oksidatif (OF) & - & - & - \\
\hline
\end{tabular}


Dengan ciri bagian permukaan kayu terdapat lapisan bakteri yang tumbuh diatas permukaan kayu (Gambar 4).

\section{Penurunan Bobot Kayu}

Standar pengujian yang diterapkan pada penelitian ini adalah menggunakan metode modifikasi dari JIS K 1571. Pengujian ini dilihat dari nilai presentasi penurunan bobot contoh uji (weight loss) yang diperoleh dari hasil penelitian di laboratorium (laboratory test). Penilaian penurunan contoh uji kayu terhadap tiga isolat bakteri merupakan nilai dari hasil pengurangan contoh uji kayu terhadap bakteri yang dilakukan selama 12 minggu. Pengujian yang telah dilakukan diperoleh nilai rata-rata penurunan bobot contoh uji kayu oleh tiga isolat bakteri (Tabel 3).

Tabel 3 memperlihatkan nilai rata-rata penurunan bobot contoh uji kayu terhadap tiga isolat bakteri berkisar antara 13.52-18.40\%. Hal ini diduga isolat bakteri yang diujikan memiliki kemampuan dalam mendekomposisi kayu. Selain itu, kayu karet memiliki kandungan selulosa yang tinggi sehingga mempengaruhi presentase penurunan bobot kayu (Herliyana et al. 2011). Pada perlakuan kontrol memiliki penurunan bobot sebanyak $1.23 \%$, hal ini diduga karena tidak diberikan perlakuan bakteri sehingga hasilnya rendah. Natalia (2011) melaporkan penurunan bobot kayu karet menggunakan jamur $P$. ostreatus memperlihatkan penurunan bobot kayu karet metode JSI arah longitudinal $9.21 \%$ dan arah cross $10.95 \%$. Jika dibandingkan dengan penurunan bobot kayu menggunakan bakteri memiliki presentase penurunan yang lebih tinggi dibandingkan dengan menggunakan jamur jamur $P$. ostreatus. Hunt dan

Tabel 3 Rata-rata presentase penurunan bobot tunggul karet dan hasil uji lanjut Duncan

\begin{tabular}{cc}
\hline \multirow{2}{*}{ Kode Isolat } & Penurunan Bobot (\%) \\
\cline { 2 - 2 } & JSI \\
\hline Kontrol & $1.23^{\mathrm{c}}$ \\
NK 4 & $13.52^{\mathrm{b}}$ \\
NS 4 & $18.40^{\mathrm{a}}$ \\
NS 5 & $17.88^{\mathrm{ab}}$ \\
\hline
\end{tabular}

Garratt (1986) melaporkan bahwa bakteri tidak mempengaruhi perubahan kayu tetapi merubah daya serap kayu terhadap cairan pada kayu. Selain itu, bakteri yang menyerang kayu hanya menggunakan senyawa- senyawa organik yang mudah dicerna yang tersimpan dalam kayu. Sehingga tampilan kayu yang diaplikasikan bakteri tidak banyak berubah. Hasil analisis ragam menunjukkan bahwa pengujian tunggul kayu menggunakan isolat bakteri berpangaruh nyata pada presentase penurunan bobot kayu (Tabel 3).

\section{SIMPULAN DAN SARAN}

\section{Simpulan}

Penelitian ini menghasilkan 111 isolat bakteri pencernaan rayap yang berasal dari kelapa sawit, rayap karet dan rayap kayu kering kontruksi. Sebanyak 31 isolat yang merupakan bakteri selulolitik. Tiga isolat bakteri selulolitik terpilih yang aman bagi tanaman dan manusia yaitu NK 4, NS 4, dan NS 5. Bakteri selulolitik NS 4 yang berasal dari rayap kelapa sawit mampu mendekomposisi tunggul karet sekitar $18.40 \%$.

\section{Saran}

Perlu dilakukan pengujian di lapang terhadap kemampuan bakteri selulolitik asal pencernaan rayap dalam dekomposisi tunggul karet.

\section{DAFTAR PUSTAKA}

Baharuddin AS, Razak MNA, Hock LS, Ahmad MN. 2010. Isolation and characterization of thermophilic cellulose-producing bacteria from empty fruit bunches-palm oil mill effluent compost. Americ J Appl Sci. 7(1):56-62.

Bajya DR, Arya D, Ranjith M, Lakharan MC, Raza SK. 2015. Isolation and identification of cellulose demoting symbionts from gut of subterranean termite, Odontotermes obesus. Indian J Agricul Sci. 85(7):970-2.

Chew YM. 2012. Isolation, identification and characterization of cellulolytic bacteria from the gut of the termite Bulbitermes constrictiforms [Tesis]. Malaysia: Faculty of Biosciences and Bioengineering, Universiti Teknologi Malaysia.

Herliyana EN, Hanifa N, Hadi YS, Arinana, Tsunoda K. 2011. Ketahanan kayu sengon terhadap Pycnophorus sanguineus dan Pleurotus djamor untuk uji Standar Nasional Indonesia (SNI) 017207.2006. J Silvikultur Tropika. 2(3):171-175.

Hunt GM, Garratt GA. 1986. Pengawetan kayu.

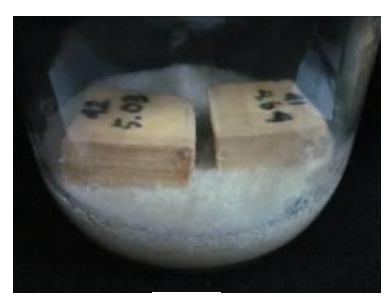

$\mathrm{a}$

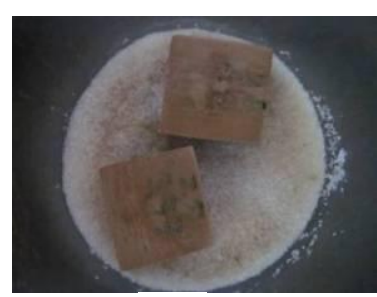

b

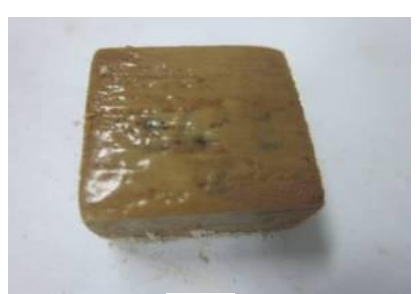

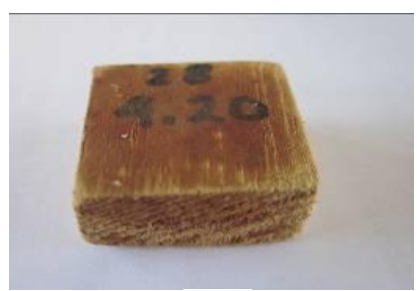

d

Gambar 4 Tampilan tunggul karet (a) contoh uji kayu hari ke-0, (b) contoh uji kayu minggu ke-12, (c) isolat bakteri yang menyelimuti permukaan contoh uji kayu, dan (d) contoh uji kayu yang sudah dibersihkan dari isolat bakteri 
Diterjemahkan Jusuf M. Akademika Jakarta (ID): Pressindo.

Igwo-Ezikpe MN, Nwahiri-Ogbu C, Oyebamiji O, Ndukwe N, Ilori MO, Ogbunugafor AH. 2013. Tropical cellulolityc bacteria isolated from hindgut of A. evuncifer: Potential candidates for bioconvension of lignocellulosic waste biomass. $J$ Basic Medical Sci. 1(1):1-6.

[JIS] Japanese Industrial Standards. 2004. Test methods for determining the effectiveness of wood preservatives and their performance requirements. JIS K 1571.

Manurung L, Lubis L, Marheni, Dalimunthe CI. 2015. Pengujian berbagai jenis bahan aktif terhadap penyakit jamur akar putih (Rigidoporus microporus (Swartz: Fr.) di Areal Tanpa Olah Tanah (TOT). J Online Agroekotek. 3(1):168-178. ISSN No. 2337-6597.

Mubin N. 2014. Analisis kekerabatan rayap tanah Macrotermes gilvus Hagen (Blattodea: Termitidae) dan inventarisasi bakteri simbionnya di Bogor [tesis]. Bogor: Departemen Proteksi Tanaman. Fakultas Pertanian, Institut Petanian Bogor.

Nandika D, Rismayadi Y, Diba F. 2015. Rayap : Biologi dan pengendaliannya, edisi 2. Surakarta (ID): Muhammadiyah University Press.

Natalia DA. 2011. Jamur tiram sebagai jamur uji keawetan alami kayu karet dan sengon dengan metode Standar Nasional Indonesia dan Standar Industri Jepang [Skripsi]. Bogor: Departemen Silvikultur. Fakultas Kehutanan, Institut Pertanian Bogor.

Ngangi J, Pelealu, J, Warouw J, Mandey L. 2013. Isolation and activity of cellulolytic bacteria isolated from hindgut of Odontotermes spa subteran termite on wasian (Elmerrelia celebica L.) an endemic wood to North Sulawesi. Int J Sci Engin Invest. 2(22):8-16.
Nogroho PA. 2012. Penyiapan lahan tanpa bakar (zero burning) dalam peremajaan tanaman karet di perkebunan komersial. Jurnal Perkebunan dan Lahan Tropika. 2(2):39-50.

Nogroho PA, Istianto. 2009. Zero burning dalam penyiapan lahan untuk perkebunan karet di Sumatera Utara. [prosiding]. Lokakarya Nasional Pemuliaan Tanaman Karet. Pusat Penelitian Karet

Pradana AP. 2016. Konsorsium bakteri endofit sebagai agens biokontrol Nematoda Puru Akar Meloidogye incognita pada Tomat. [Tesis]. Bogor: Sekolah Pascasarjana. Institut Pertanian Bogor.

Pourramezan Z, Ghezelbash GR, Romani B, Ziaei S, Hedayatkhah A. 2012. Screening and identification of newly isolated cellulose-degrading bacteria from the gut of Xylophagous termite Microcerotermes diversus (Silvestri). Microbiol. 81(6):736-742.

Rupaedah B. 2014. Peranan fungi mikoriza arbuskular dan rhizobakteri dalam meningkatkan produksi gula dan efisiensi penyerapan hara sorgum manis (Sorgum bicolor L. Moench) [Disertasi]. Bogor: Program Pascasarjana. Program Studi Ilmu Tanah, Institut Pertanian Bogor.

Sunatmo TI. 2009. Eksperimen mikrobiologi dalam laboratorium. Jakarta (ID) : Ardy Agency.

Suryanto D, Irmayanti, Lubis S. 2007. Karakterisasi dan uji kepekaan antibiotik beberapa isolat Staphylococcus aureus dari Sumatera Utara. Majalah Kedokteran Nusantara. 40(2):104-107.

Upadhyaya SK, Manandhar AM, Mainali H, Pokhrel AR, Rijal A, Pradhan B, Koirala B. 2012. Isolation and characterization of cellulolytic bacteria from gut of termite. Rentech Symp Compend. 1:14-18. 